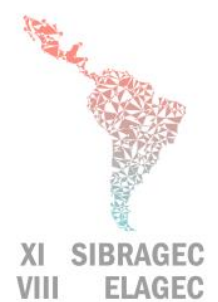

VIII ELAGEC
XI SIMPÓSIO BRASILEIRO DE GESTÃO E ECONOMIA DA CONSTRUÇÃO

VIII ENCUENTRO LATINOAMERICANO DE GESTIÓN Y ECONOMÍA DE LA CONSTRUCCIÓN

From knowledge to action: advanced practice in production management

Londrina, Paraná, Brasil. From 23 to 25 October, 2019

\title{
BENEFITS OF LAST PLANNER® SYSTEM IN MITIGATION OF DELAY CAUSES IN ROAD INFRASTRUCTURE PROJECTS
}

\author{
SANCHEZ, Omar G. (1); CASTAÑEDA, Karen M. (2); HERRERA, Rodrigo F. \\ (3); PELLICER, Eugenio (4)
}

(1) Universidad Industrial de Santander, +5776344000, omar.sanchez@ correo.uis.edu.co; (2) Universidad Industrial de Santander, +5776344000, karencasta.ing@outlook.es; (3) Pontificia

Universidad Católica de Valparaíso, Pontificia Universidad Católica de Chile +56944132109 , rodrigo.herrera@pucv.cl; (4) Universitat Politècnica de València, +34963879562, pellicer@upv.es

\begin{abstract}
Delay is a phenomenon that affects road infrastructure projects around the world with serious consequences. The study of methodologies that allow mitigate delay causes is a key issue. One option is Last Planner ${ }^{\circledR}$ System (LPS) that is a collaborative planning method that improves the fulfillment of construction activities in time. LPS has the characteristics for mitigate delay causes in early stages and avoid delays happening during the projects. This study analyzes delay causes mitigation through LPS implementation in road infrastructure projects. The research method consisted in: literature review of the main delay causes in road infrastructure projects, benefits identification of LPS implementation in 10 road projects and analysis of relations between delay causes and LPS benefits. The results indicate that many delay causes in road infrastructure projects have relation with: financial difficulties by owner, shortage of materials, inadequate contractor experience. On the other side, the implementation of LPS provides benefits in: time reduction, improvement in communication, early identification of problems and others. Relations between delay causes and benefits show that LPS is an efficient tool for mitigate delay causes in road infrastructure projects.
\end{abstract}

Keywords: Delay causes, Delay factors, Road infrastructure, Last Planner System.

\section{INTRODUCTION}

Timely completion of road infrastructure projects is considered one of the most important success factors (Aziz \& Abdel-Hakam 2016), however, deliver projects within schedule and budget has been a challenge in the construction industry. Amoatey \& Okanta (2017) found that about $70 \%$ of road projects are affected by delays and $52 \%$ by cost overruns. This failures have caused that many professionals and researchers intent to identify and mitigate the causes of the problems. In search for delay causes, defects in planning has been identified as a critical factor that contribute to delay in road construction projects (Karunakaran et al. 2018).

Within project planning methods, Last Planner® System (LPS) has had great acceptance. LPS is a planning system that procures the reduction of workflow uncertainty (Ballard 2000) through four levels of planning (Alarcón \& Pellicer 2009): 1) master schedule, 2) phase schedule, 3) look-ahead planning and 4) weekly work plans. Fernandez et al. (2013) studied 26 construction projects with LPS implementation; the benefits identified were: 1) smooth workflow, 2) predictable work plans, 3) reduced 
cost, 4) reduced time of project delivery, 5) improved productivity, and 6) greater collaboration with field personnel and subcontractors. Nevertheless, LPS has been implemented mainly in building projects, while in road infrastructure projects the use has been scarce (Ahiwako et al. 2015).

Considering this gap, the goals of this paper are, on the one hand, to identify benefits of LPS implementation in road infrastructure projects and, on the other hand, to identify delay causes in road infrastructure that could be mitigated with LPS implementation. The research method consisted on a literature review of delay causes in road infrastructure projects, later an analysis of cases study of road infrastructure projects with LPS implementation and, finally, an analysis of the relations between delay causes and LPS benefits.

\section{MATERIALS AND METHODS}

The review of delay causes in road infrastructure projects was through a systematic review with three inclusion/exclusion criteria for the document selection: 1) study of delay causes in construction projects, 2) ranking of 10 most important delay causes and 3) type of project (road infrastructure). A total of 295 documents were collected and finally 15 were selected for in-depth analysis (see Table 1); all of them were focused on road infrastructure projects. The selection of delay causes came from the 10 most important causes reported in the 15 documents selected; the process consisted in assign an inverse rank (IR) according to the rank reported (RR). For example, Aziz \& AbdelHakam (2016) report: owner financial problems with rank 1, thus inverse rank is 10 ; shortage in equipment with rank 2 , thus inverse rank is 9 .

$$
I R=10-(R R-1)
$$

Table 1 - Studies on delay factors of road infrastructure projects by country

\begin{tabular}{|c|l|}
\hline Country & \multicolumn{1}{|c|}{ Reference } \\
\hline Algeria & (Rachid et al. 2018) \\
\hline Cambodia & (Santoso et al. 2016) \\
\hline Egypt & (Aziz \& Abdel-Hakam 2016) \\
\hline Ghana & (Amoatey \& Okanta 2016) \\
\hline India & (Venkateswaran \& Murugasan 2017) \\
\hline Iraq & (Hadithi 2018) \\
\hline Kenya & (Seboru 2015) \\
\hline Lybia & (Youniss et al. 2017) \\
\hline Malawi & (Kamanga \& Wynandsteyn 2013) \\
\hline Malaysia & (Karunakaran et al. 2018) \\
\hline Nigeria & (Omoregie \& Radford 2006) \\
\hline Pakistan & (Sohu et al. 2019) \\
\hline Palestine & (Mahamid et al. 2012) \\
\hline Saudi Arabia & (Elawi et al. 2015) \\
\hline Thailand & (Thapanont et al. 2018) \\
\hline
\end{tabular}


The delay causes were grouped by similarity, obtaining an overall important rank $(O I R)$ from the sum of individual inverse ranks $(I R)$ for each $k$ delay cause. Finally, the 10 delay causes with higher $O I R$ were selected (see Table 2).

$$
O I R_{k}=\sum_{i=1}^{15} I R_{i}
$$

Table 2 - Main causes of delay on road infrastructure projects

\begin{tabular}{|c|l|c|}
\hline Id & \multicolumn{1}{|c|}{ Delay cause } & OIR \\
\hline D1 & Financial difficulties by owner & 107 \\
\hline D2 & Shortage of materials & 69 \\
\hline D3 & Inadequate contractor experience & 56 \\
\hline D4 & Weather & 46 \\
\hline D5 & Land acquisition & 44 \\
\hline D6 & Failures in design & 41 \\
\hline D7 & Shortage in equipment & 41 \\
\hline D8 & Inadequate project planning & 38 \\
\hline D9 & Poor site management & 55 \\
\hline D10 & Delays in activities & 29 \\
\hline
\end{tabular}

\section{BENEFITS OF LPS IMPLEMENTATION IN ROAD PROJECTS}

The identification of LPS benefits was performed through an analysis of the literature of studies implementing LPS applied to road infrastructure projects. The initial sample consisted of about 50 cases and most of them were discarded because they were focused on building projects. The final sample were comprised of 10 cases (see Table 3 ) located in: Africa, Asia, Europe and South America. Most cases come from the UK, where Highways England (a governmental agency responsible for the operation and maintenance of England's highways) has implemented successfully LPS in road infrastructure projects (Fullalove 2013); Highways England has the target of $£ 1.2$ billion cost savings using Lean techniques (including LPS), from 2015 to 2020 period (Sullivan 2016).

Table 3 - Studies on LPS implementation in road infrastructure projects

\begin{tabular}{|c|c|l|c|c|}
\hline Case & Reference & \multicolumn{1}{|c|}{ Project } & $\begin{array}{c}\text { Stage with } \\
\text { LPS }\end{array}$ & Location \\
\hline C1 & $\begin{array}{c}\text { (Ansell et al. } \\
\text { 2007) }\end{array}$ & 3 miles of carriageways renewal & $\begin{array}{c}\text { Design, } \\
\text { Construction }\end{array}$ & UK \\
\hline C2 & (Jang et al. 2007) & Nam Chun Highway project & Construction & South Korea \\
\hline C3 & (Jang et al. 2007) & Seoul Ring Road project & Construction & South Korea \\
\hline C4 & (Olano et al. 2009) & 7 km highway construction & Construction & Peru \\
\hline C5 & (Chen et al. 2012) & $\begin{array}{l}\text { Asphalt laying on the A1 Dishforth } \\
\text { to Leeming }\end{array}$ & Construction & UK \\
\hline C6 & (Chen et al. 2012) & $\begin{array}{l}\text { The M53 Bidston Moss viaduct } \\
\text { strengthening }\end{array}$ & $\begin{array}{c}\text { Design, } \\
\text { Construction }\end{array}$ & UK \\
\hline
\end{tabular}


SIBRAGEC - ELAGEC 2019 - From 23 to 25 October - LONDRINA - PR

Table 3 - Studies on LPS implementation in road infrastructure projects (cont.)

\begin{tabular}{|c|c|l|l|c|}
\hline C7 & (Fullalove 2013) & $\begin{array}{l}28 \text { km of dual carriageway } \\
\text { construction }\end{array}$ & Construction & UK \\
\hline C8 & $\begin{array}{c}\text { (Ahiwako et al. } \\
\text { 2015) }\end{array}$ & $\begin{array}{l}4 \text { km standard single carriageway } \\
\text { road construction }\end{array}$ & Construction & Nigeria \\
\hline C9 & (Daniel 2017) & $\begin{array}{l}\text { Upgrade to replace dual carriageway } \\
\text { with a three lane motorway }\end{array}$ & $\begin{array}{c}\text { Design, } \\
\text { Construction }\end{array}$ & UK \\
\hline C10 & (Daniel 2017) & $\begin{array}{l}\text { Improve motorway to smart } \\
\text { motorway }\end{array}$ & Construction & UK \\
\hline
\end{tabular}

Table 4 displays the benefits of LPS implementation. Some of these benefits of LPS implementation are: reduction of variability, improvement in team motivation, empowerment of the project team, early participation of stakeholders, reduction of equipment usage, risks reduction, better production control, opportunity for buildability/constructability review, improvement of quality, re-work reduction, and more efficiency in the construction process.

Table 4 - Main benefits of LPS implementation in road infrastructure projects

\begin{tabular}{|c|l|c|}
\hline Id & \multicolumn{1}{|c|}{ Benefit of LPS implementation } & Project code \\
\hline B1 & Reduction of time duration of construction activities & C1,C4,C5,C6,C7,C8,C9,C10 \\
\hline B2 & $\begin{array}{l}\text { Improvement in communication and transparency } \\
\text { among the project's stakeholders }\end{array}$ & C2,C3,C6,C7,C9,C10 \\
\hline B3 & Early identification of key barriers & $\mathrm{C} 1, \mathrm{C} 5, \mathrm{C} 6, \mathrm{C} 7, \mathrm{C} 8, \mathrm{C} 10$ \\
\hline B4 & Safety improvement & $\mathrm{C} 5, \mathrm{C} 7, \mathrm{C} 8, \mathrm{C} 9, \mathrm{C} 10$ \\
\hline B5 & Cost reduction & $\mathrm{C} 5, \mathrm{C} 6, \mathrm{C} 7, \mathrm{C} 9$ \\
\hline B6 & Collaboration in decision-making & $\mathrm{C} 2, \mathrm{C} 3, \mathrm{C} 8, \mathrm{C} 9$ \\
\hline B7 & Improvement planning and the reliability of plans & $\mathrm{C} 1, \mathrm{C} 4, \mathrm{C} 7, \mathrm{C} 8$ \\
\hline B8 & Improvement of the workflow reliability & $\mathrm{C} 4, \mathrm{C} 6, \mathrm{C} 7$ \\
\hline B9 & Design improvement & $\mathrm{C} 6, \mathrm{C} 9$ \\
\hline B10 & Logistic improvement & $\mathrm{C} 5, \mathrm{C} 8$ \\
\hline
\end{tabular}

\section{RELATION BETWEEN DELAY CAUSES AND LPS BENEFITS}

The next step was identify relationships between delay causes (10 identified in Table 2) and benefits of LPS implementation (10 identified in Table 4). The result was a matrix with 45 relations displayed in Table 5. 
SIBRAGEC - ELAGEC 2019 - From 23 to 25 October - LONDRINA - PR

Table 5 - Relationships between delay causes and LPS benefits

\begin{tabular}{|c|l|c|c|c|c|c|c|c|c|c|c|}
\hline \multirow{2}{*}{ Id } & \multicolumn{1}{|c|}{ Delay cause } & \multicolumn{7}{|c|}{ Benefits of LPS in road projects* } \\
\hline & \multicolumn{1}{|c|}{} & B1 & B2 & B3 & B4 & B5 & B6 & B7 & B8 & B9 & B10 \\
\hline D1 & Financial difficulties by owner & & & $\checkmark$ & & $\checkmark$ & & & & & \\
\hline D2 & Shortage of materials & & $\checkmark$ & $\checkmark$ & & & & $\checkmark$ & $\checkmark$ & & $\checkmark$ \\
\hline D3 & $\begin{array}{l}\text { Inadequate contractor } \\
\text { experience }\end{array}$ & & & & $\checkmark$ & & $\checkmark$ & & & & \\
\hline D4 & Weather & & & $\checkmark$ & & & $\checkmark$ & $\checkmark$ & & & \\
\hline D5 & Land acquisition & & & $\checkmark$ & & & $\checkmark$ & $\checkmark$ & $\checkmark$ & & \\
\hline D6 & Failures in design & & $\checkmark$ & $\checkmark$ & & & $\checkmark$ & & & $\checkmark$ & \\
\hline D7 & Shortage in equipment & & $\checkmark$ & $\checkmark$ & & & & $\checkmark$ & $\checkmark$ & & $\checkmark$ \\
\hline D8 & Inadequate project planning & $\checkmark$ & $\checkmark$ & $\checkmark$ & $\checkmark$ & & $\checkmark$ & $\checkmark$ & & $\checkmark$ & \\
\hline D9 & Poor site management & $\checkmark$ & $\checkmark$ & $\checkmark$ & $\checkmark$ & & $\checkmark$ & $\checkmark$ & & & \\
\hline D10 & Delays in activities & $\checkmark$ & & $\checkmark$ & $\checkmark$ & & $\checkmark$ & $\checkmark$ & $\checkmark$ & $\checkmark$ & $\checkmark$ \\
\hline
\end{tabular}

* Codes according to Table 4 .

Inadequate project planning, poor site management and delays in critical activities are the causes of delays in road construction that can be reduced or mitigated by the greater amount of LPS benefits. This is because LPS is a tool that allows to standardize the management in an engineering project using a collaborative and gradual approach (Ballard \& Howeell 2003). Collaboration generates transparent work environments that strengthen trust among team members, achieving reliable commitments in the fulfillment of tasks based on real and updated information (Salazar et al. 2018). The gradual planning allows to have updated information to execute the tasks in the medium and short term. A better communication and transparency between the team members allows to manage correctly both, early stages and the construction site (Rodríguez et al. 2011).

The shortage of materials or equipment can be reduced when applying LPS, since with this tool it is possible to identify restrictions to progress in order to anticipate and minimize these problems. In addition, if the planning and workflow is reliable, it is possible to have a defined logistics for the delivery of materials and availability of machinery and equipment (Zegarra \& Alarcón 2013). In the same way it is possible to anticipate failures in the design, since the verification of the design is a restriction that must be released in the look ahead planning before the planning of any activity in the short term schedule (Matta et al. 2018).

On the other hand, there are some causes of delay such as financial difficulties by owner and land acquisition that are more difficult to solve with LPS, since they depend on a different level of planning. However, if these causes are considered as restrictions, it can be anticipated in the phase plan or in the look ahead planning; the objective is not making decisions before these key factors are solved and, therefore, not assuming costs for having idle workforce. The inadequate experience of the contractor is difficult to solve with the application of LPS in the project execution; however, if collaborative decision making is implemented in early stages, the choice of contractor may be more appropriate. Finally, weather is a cause of delay that cannot be eliminated, but it is possible to plan considering this factor when defining resources for short-term activities. 


\section{CONCLUSIONS}

Benefits of LPS implementation in road infrastructure include, among others (Table 4): 1) reduction of time duration of construction activities; 2) improvement in communication and transparency among the stakeholders on the project; 3) early identification of key barriers to progress and anticipate, minimizing daily problems; and 4) improvement in safety. The delay causes in road projects that are possible to mitigate with LPS implementation are, among others (Table 5): 1) delays in activities; 2) inadequate project planning; 3 ) poor site management; and 4) shortage of materials and equipment. Results show that LPS implementation in road infrastructure projects has the potential for mitigate delay causes through an improvement in planning activities. The limitations were the low number of road infrastructure projects with LPS implementation reported in the literature and the lack of studies of delay causes of road infrastructure projects in Europe and America. Future works can focuses in exploration, analysis and categorization of the relationships between LPS benefits and delay causes.

\section{REFERENCES}

AHIAKWO, O.; DAVID, O.; SUBASHINI, S.; JAMAL K. 2015. Implementing The Last Planner System in a Road Construction Project in Nigeria. Built Environment Journal, v. 12, n. 2, p. 32-49, Jul. 2015.

ALARCÓN, L.; EUGENIO P. Un Nuevo Enfoque en la Gestión: La Construcción Sin Pérdidas. Revista de Obras Públicas, v. 156, n. 3496, p. 45-52, Feb. 2009.

AMOATEY, C.; ALFRED O. Exploring Critical Road Project Delay Factors in Ghana. Journal of Facilities Management, v. 15, n. 2, p. 110-27, Nov. 2016

ANSELL, M.; HOLMES, M.; EVANS, R.; PASQUIRE, C.; PRICE, A. Lean Construction Trial on a Highways Maintenance Project. In: Annual Conference of the International Group for Lean Construction, 15, Michigan: IGLC/LUIR, 2007.

AZIZ, F.; ASMAA A. Exploring Delay Causes of Road Construction Projects in Egypt. Alexandria Engineering Journal, v. 55, n. 2, p. 1515-39, Mar. 2016.

BALlarD, G. The Last Planner System of Production Control. 2000. Thesis (Doctor of Philosophy) - School of Civil Engineering, Faculty of Engineering, The University of Birmingham, Birmingham.

BALLARD, G.; GREGORY, H. An Update on Last Planner. In: Conference of the International Group for Lean Construction, 11, Virginia: IGLC/UB, 2003.

CHEN, C.; SUE H.; PAUL S.; PHIL, G. Introducing Lean into the UK Highways Agency's Supply Chain. In ICE-Proceedings of the Institution of Civil Engineers, v. 165, p. 34-39, May. 2012.

EMMANUEL, D. Exploratory Study into the Use of Last Planner ${ }^{\circledR}$ System and Collaborative Planning for Construction Process Improvement. 2017. Thesis (Doctor of Philosophy) - Nottingham Trent University, Nottingham.

ELAWI, G.; MOHAMMED A.; DEAN K.; KENNETH S. Major Factors Causing Construction Delays in Mecca. Journal for the Advancement of Performance Information, v. 7, n. 1, p. 111, 2015.

FERNANDEZ, J.; PORWAL, V.; LAVY, S.; SHAFAAT, A.; RYBKOWSKI, Z.; SON, K.; LAGOO, N. Survey of Motivations, Benefits, and Implementation Challenges of Last Planner System Users. Journal of Construction Engineering and Management, v. 139, p. 354-60, Apr. 2013. 


\section{SIBRAGEC - ELAGEC 2019 - From 23 to 25 October - LONDRINA - PR}

FULLALOVE, L. Examples of Lean Techniques and Methodology Applied to UK Road Schemes. In: Conference of the International Group for Lean Construction, 21, Fortaleza: IGLC, 2013.

HADITHI, B. An Investigation into Factors Causing Delays in Highway Construction Projects in Iraq. In: Matec Web of Conferences. BCEE, 2017.

JANG, W.; YONG, K.; CHAN P.; WOO J. Importance of Partners in a Challenging Lean Journey. In: Conference of the International Group for Lean Construction, 15, Michigan: IGLC, 2007.

KAMANGA, M.; P WYNANDSTEYN. Causes of Delay in Road Construction Projects in Malawi. Journal of the South African Institution of Civil Engineering, v. 55, n. 3, p. 79-85, Oct. 2013.

KARUNAKARAN, S.; RAML, M.; MALEK, M.; MUSIR, A.; IMRAN, N.; FUAD, M.; ZAWAWI, M.; ZAINAL, M. Causes of Delay on Highway Construction Project in Klang Valley Causes of Delay on Highway Construction Project in Klang. In: Green Design and Manufacture: Advanced and Emerging Applications, AIP Conference, 2018.

MAHAMID, I.; AMUND B.; NABIL D. Causes of Delay in Road Construction Projects. Journal of Management in Engineering, v. 28, n. 3, p. 300-310, Jul. 2012.

MATTA, G.; HERRERA, R.; BALADRÓN, C.; GIMÉNEZ, Z.; ALARCÓN, L.; Using BIMBased Sheets as a Visual Management Tool for on-Site Instructions: A Case Study. In: Conference of the International Group for Lean Construction, 26, Chennai: IGLC, 2018.

OLANO, R.; ALARCÓN, L.; RÁZURI, C. Understanding the Relationship between Planning Reliability and Schedule Performance: A Case Study. In: Annual Conference of the International Group for Lean Construction, 17, Chile: IGLC, 2009.

OMOREGIE, A, AND D RADFORD. Infrastructure Delays and Cost Escalation: Causes and Effects in Nigeria. In: Conference in the Built and Human Environment, 6, England: SAMU, 2006.

ZEMRA, R.; TOUFIK, B.; MOHAMMED, B. Causes of Schedule Delays in Construction Projects in Algeria. International Journal of Construction Management, p. 1-11, Mar. 2018.

RODRÍGUEZ, A.; ALARCÓN, L.; PELLICER, E. La Gestión de la Obra desde la Perspectiva del Último Planificador. Revista de Obras Públicas, v. 158, n. 3518, p. 1-9, Feb. 2011.

SALAZAR, L.; BALLARD, G.; ARROYO, P.; ALARCÓN L. Indicators for Observing Elements of Linguistic Action Perspective in Last Planner ${ }^{\circledR}$ System. In: Conference of the International Group for Lean Construction, 26, Chennai: IGLC, 2018.

SANTOSO, S.; SOENG, S. Analyzing Delays of Road Construction Projects in Cambodia: Causes and Effects. Journal of Management in Engineering, v. 32, n. 6, p. 1-11, 2016.

SEBORU, M. An Investigation into Factors Causing Delays in Road Construction Projects in Kenya. American Journal of Civil Engineering, v. 3, n. 3, p. 51-63, Apr, 2015.

SOHU, S.; CHANDIO, A.; KALEEMULLAH. Identification of Causes and Minimization of Delays in Highway Projects of Pakistan. Mehran University Research Journal of Engineering \& Technology, v. 38 n. 1, p. 103-12. Feb, 2019

SULLIVAN, J. 2016. Lean Support to Highways England. Highways England, 2015 - 2020.

PORNSIRICHOTIRAT, T.; CHAROENPORNPATTANA, S.; XINGHATIRAJ P. Causes of Delay on Highway Construction Projects in Thailand. In: Matec Web of Conferences, ICEAST, 2018.

VENKATESWARAN, C.; MURUGASAN, R. Time Delay and Cost Overrun of Road over Bridge (ROB) Construction Projects in India. Journal of Construction in Developing Countries, v. 22, n. 11, p. 79-96, Nov. 2017. 
ABOUBAKER, A.; AMIRUDDIN, I.; MUHAMAD, A.; ISHAK, A.; HAMZA, I. A Conceptual Model of Delay Factors Affecting Road Construction Projects in Libya. Journal of Engineering Science and Technology, v. 12, n. 1, p. 3286-98, Jan. 2017.

ZEGARRA, O.; ALARCÓN, L. Propagation and Distortion of Variability into the Production Control System: Bullwhip of Conversations of the Last Planner. In: Conference of the International Group for Lean Construction, 21, Fortaleza, IGLC, 2013.

\section{ACKNOWLEDGMENTS}

Omar Sánchez thanks to Colciencias for the support through Convocatoria Doctorados Nacionales 2015. Rodrigo Herrera acknowledge to CONICYT - PCHA/National Doctorate/2018 - 21180884 for funding the graduate research. 